\title{
DINAMIKA POPULASI DAN LAJU EKSPLOITASI CUMI-CUMI (Sepioteuthis Lessoniana) DI KEPULAUAN SPERMONDE SULAWESI SELATAN
}

\section{(Population Dynamics and Exploitation Rate of Squid (Sepioteuthis lessoniana) in Spermonde Islands, South Sulawesi)}

\author{
Ernaningsih 1), Muhammad Jamal 2), Nur indah ${ }^{3)}$ \\ 1,2 Prodi Pemanfaatan Sumberdaya Perikanan FPIK UMI Makassar \\ 3). Mahasiswa Prodi Pemanfaatan Sumberdaya Perikanan FPIK UMI Makassar
}

Korespondensi: ernaningsih36@yahoo.co.id

Diterima: tanggal 2 Agustus 2019; Disetujui 15 Oktober 2019

\begin{abstract}
Squid Sepioteuthis lessoniana is a sought-after fisheries commodity, leading to a high exploitation rate. This affects the sustainability of Squid (S. lessoniana) resources in wild, especially Spermonde Island. The aim of this study was to determine the population dynamics and the exploitation rate of Squid (S. lessoniana) in the Spermonde Islands of South Sulawesi. The results of the study are expected to provide information on the level of utilization of Squid and as a basis for sustainable management of squid in Spermonde Islands. The present study was conducted from March to July 2019 in Spermonde Islands, South Sulawesi. A survey was performed by direct measurement of the fish captured by local fishermen and merchants. Data collected on length and weight of squid were carried out for 3 or 4 times a week. The results showed length of squid ranged from 06 to $28 \mathrm{~cm}$, the relationship between the length of the weight was negative allometric, the age group consisted of 4 , the growth rate $(\mathrm{K})$ of 0.37 per year, the maximum length $(\mathrm{L} \max )$ of $31.5 \mathrm{~cm}$, the total mortality rate $(\mathrm{Z})$ of 2.85 per year, the natural mortality rate $(\mathrm{M})$ of 0.95 per year, the capture mortality rate (F) of 1.90 per year and the exploitation rate is classified into over-exploitation.
\end{abstract}

Keywords: Growth rate, exploitation rate, Squid, Spermonde Islands

\begin{abstract}
ABSTRAK
Cumi Cumi (Sepioteuthis lessoniana) salah satu sumberdaya hasil perikanan bernilai ekonomis. Kepulauan Spermonde merupakan salah satu wilayah dimana penangkapan cumi cumi banyak dilakukan oleh nelayan. Intensitas penangkapan yang tinggi dapat berpengaruh terhadap keberlanjutan sumberdaya Cumi Cumi (S. lessoniana). Penelitian ini bertujuan yaitu untuk menganalisis dinamika populasi dan laju eksploitasi Cumi Cumi (S. lessoniana) di Kepulauan Spermonde Sulawesi Selatan.. Hasil penelitian diharapkan memberikan informasi tingkat pemanfaatan Cumi Cumi dan sebagai dasar dalam pengelolaan secara berkelanjutan. Penelitian dilaksanakan pada bulan April - Juli 2019 di Kepulauan Spermonde Sulawesi Selatan. Metode penelitian yang digunakan adalah metode survey yaitu dengan cara melakukan pengukuran secara langsung hasil tangkapan nelayan dan pedagang pengumpul. Data biologi yang dikumpulkan adalah data panjang dan berat Cumi-cumi (S. lessoniana). Pengambilan sampel dilakukan 3-4x seminggu. Hasil penelitian Cumi Cumi (Sepioteuthis lessoniana) menunjukkan kisaran panjang 06-28 $\mathrm{cm}$, hubungan panjang berat bersifat allometrik minor, kelompok umur terdiri atas 4, kecepatan pertumbuhan (K) sebesar 0,37 per tahun, Pjg maksimum (L maks) 31,5 cm, laju mortalitas total (Z) 2,85 pertahun, laju mortalitas alami (M) 0.95 per tahun, laju mortalitas penangkapan (F) 1,90 per tahun dan laju eksploitasi telah mengalami tangkap lebih (over eksploitasi)
\end{abstract}

Kata kunci : Laju pertumbuhan, laju eksploitasi, Cumi Cumi, Kepulauan Spermonde 


\section{PENDAHULUAN}

Cumi-cumi

$(S$.

Lessoniana)

merupakan salah satu komuditas perikanan bernilai ekonomis penting. Permintaan terhadap cumi-cumi terus meningkat. Kecenderungan ini akan mendesak para nelayan untuk melakukan penangkapan secara intensif, sementara diketahui bahwa produksi cumi-cumi masih tergantung pada stok di alam sehingga dikhawatirkan intensifikasi penangkapan pada suatu saat akan mengancam kelestarian sumberdaya komoditi ini.

Selama periode Tahun 2008 sampai dengan 2012, produksi Cumicumi cenderung berfluktuatif dengan produksi rata-rata sebanyak 207,3 ton. Produksi tertinggi dicapai pada tahun 2008, dengan volume produksi sebanyak 272,9 ton dan produksi terendah terjadi pada tahun 2011, dengan volume produksi sebanyak 146,7 ton (Kurniawan, 2014). Produksi yang fluktuatif dan cenderung menurun dapat berpengaruh terhadap keberlanjutan sumberdaya cumi cumi dan tidak menutup kemungkinan terjadinya kelebihan tangkap (over eksploitasi).

Penangkapan ikan menyebabkan hilangnya ikan berukuran besar dan spesies yang paling rentan dari populasi.

Degradasi habitat akan mempengaruhi penangkapan dengan pengurangan tangkapan spesies target (Wilson et al, 2010). Kepulauan Spermonde merupakan daerah penangkapan Cumi cumi oleh nelayan, dimana hasil penelitian Ernaningsih (2015), memperlihatkan telah terjadinya kerusakan habitat karang di Kepulauan Spermonde akibat penangkapan yang tidak ramah lingkungan. Pengelolaan sumberdaya perikanan merupakan usaha yang dilakukan untuk meningkatkan eksploitasi sumberdaya perikanan dengan tetap menjaga kelestariannya. Pengelolaan efektif terhadap sumberdaya karang tergantung pada pengaturan tekanan penangkapan dan proses pemeliharaan dan pemulihan habitat karang (Wilson et al, 2010). Analisis parameter populasi dan tingkat eksploitasi Cumi cumi ( S. Lessoniana) di Kepulauan Spermonde merupakan kajian penting dan sebagai informasi dasar dalam upaya mempertahankan kelestarian sumberdaya tersebut. Dari uraian diatas dapat dirumuskan beberapa masalah yang penting, yaitu: bagaimana paramter populasi Cumi cumi $(S$. Lessoniana) meliputi: hubungan panjang berat, sebaran ukuran, kelompok umur, 
laju pertumbuhan dan laju kematian di Kepulauan Spermonde Sulawesi Selatan dan bagaiman laju eksplotasi Cumi cumi (S. Lessoniana) di Kepulauan Spermonde Sulawesi Selatan. Penelitian ini bertujuan untuk: 1) Menganalisis parameter populasi Cumi cumi (S. Lessoniana) meliputi: hubungan panjang berat, sebaran ukuran, kelompok umur, laju pertumbuhan dan laju kematian di
Kepulauan Spermonde Sulawesi Selatan dan 2) Menganalisis laju eksplotasi Cumi cumi (S. Lessoniana) di Kepulauan Spermonde Sulawesi Selatan.

\section{METODE PENELITIAN}

Penelitian ini telah dilaksanakan mulai dari bulan April 2019 - Juli 2019, di Kepulauan Spermonde Sulawesi Selatan

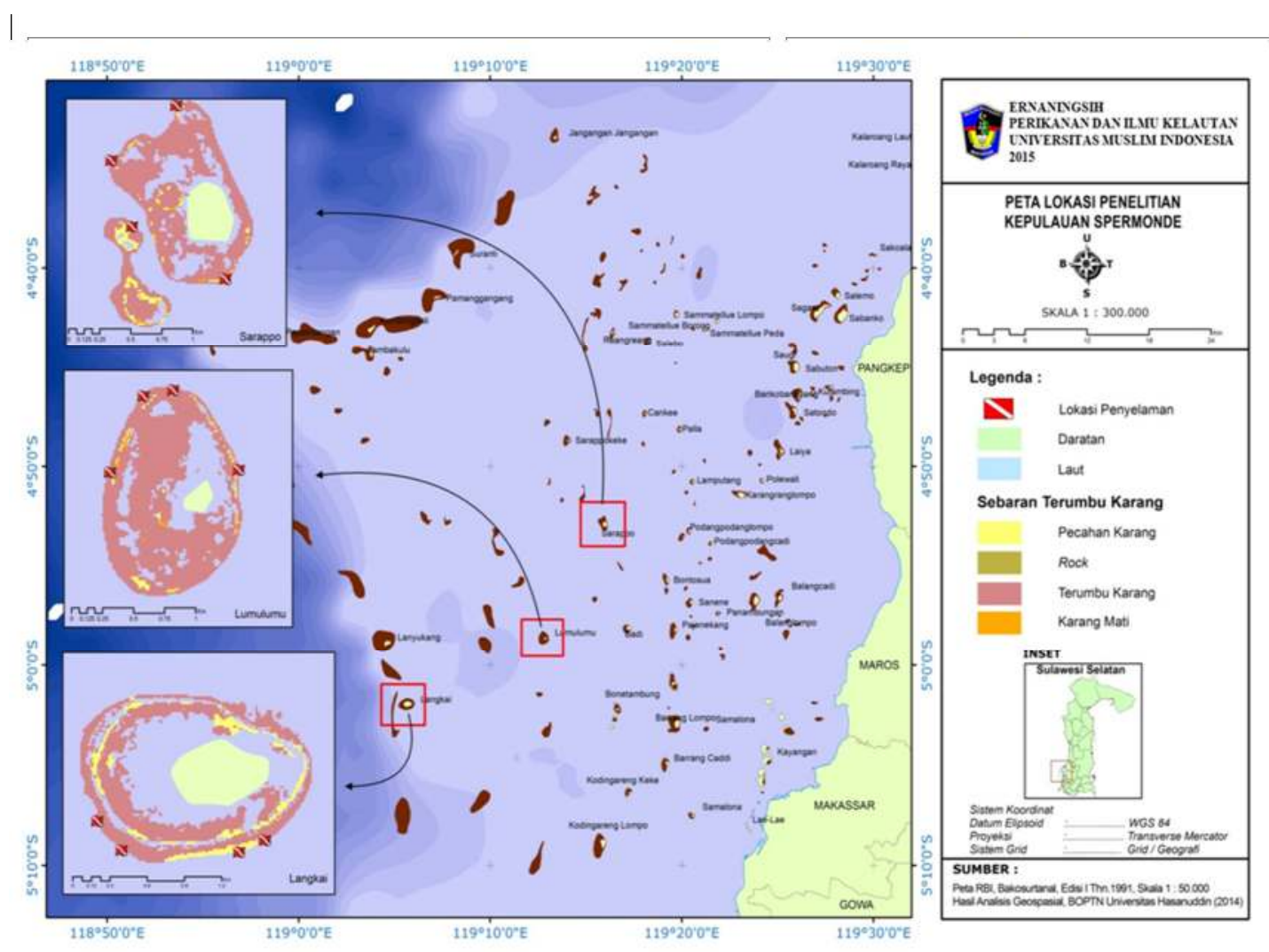

Gambar 1. Peta lokasi penelitian 
Alat dan bahan yang digunakan pada penelitian seperti pada Tabel 1.

Tabel 1. Alat dan Bahan Penelitian

\begin{tabular}{|c|l|lr|}
\hline No & \multicolumn{1}{|c|}{ Alat dan Bahan } & \multicolumn{1}{|c|}{ Keterangan } \\
\hline 1 & Timbangan Digital & Mengukur berat Cumi Cumi \\
\hline 2 & Papan ukur & $\begin{array}{l}\text { Mengukuran panjang mantel } \\
\text { CumiCumi }\end{array}$ \\
\hline 3 & Kamera digital & $\begin{array}{l}\text { Mengambil gambar sampel dan } \\
\text { kegiatan di lapangan. }\end{array}$ \\
\hline 4 & Alat Tulis-Menulis & Mencatat hasil pengukuran & \\
\hline 5 & Termometer & Mengukur suhu permukaan air & \\
\hline 6 & Cumi Cumi (S. Lessoniana) & Organisme uji \\
\hline
\end{tabular}

Pengambilan sampel dilakukan pada lokasi nelayan yaitu Pulau Balang lompo dan Pulau Badi yang juga merupakan daerah tangkapan Cumi Cumi (S. Lessoniana) di wilayah kepulauan Spermonde. Pengukuran parameter populasi dilakukan dengan mengukur panjang mantel $(\mathrm{cm})$ dan berat (gram) Cumi Cumi (S. Lessoniana) yang tertangkap dengan pancing. Pengambilan sampel dilakukan pada tingkat nelayan dan pedagang pengumpul (tempat pengumpulan Cumi Cumi dimana nelayan mendaratkan hasil tangkapannya). Pengambilan sampel dilakukan 2-3 kali seminggu.

Penentuan sebaran ukuran panjang dianalisis secara deskriptif dan analisis parameter populasi ikan dilakukan dengan menggunakan paket program ELEFAN dalam FiSAT II (Gayanilo et al, 2005).
Pendugaan umur dengan analisis frekuensi panjang, yang merupakan metode yang cocok diterapkan di perairan tropis karena dapat memisahkan komponen-komponen kelompok umur (Pauly, 1980). Untuk memisahkan kelompok umur data dianalisis dengan metode Bhattacharya. Setelah memperoleh kelompok-kelompok umur yang terpisah, maka dapat dihitung laju pertumbuhan. Metode numerik telah dikembangkan yang dapat mengkonversikan data frekuensi panjang ke komposisi umur yaitu Metode Von Bertalanffy (Sparre, 1992).

Model matematika dari persamaan pertumbuhan von Bertalanffy adalah sebagai berikut :

$L_{t} \quad=L \infty\left(1-e-K\left(t-t_{0}\right)\right) \ldots \ldots \ldots$ (1)

Untuk menentukan nilai $L \infty$ dan $\mathrm{K}$ digunakan metode Gulland dan Holt (dalam Sparre, 1992), Untuk 
mengetahui to adalah dengan alami dan mortalitas akibat menggunakan persamaan empiris Pauly penangkapan, sehingga diperoleh (1980), yaitu : persamaan :

$$
\begin{aligned}
& \log (- \text { to })=-0,3922-0,2752 \log \\
& \text { L.. - } \log \mathrm{K}
\end{aligned}
$$$$
\begin{array}{rr}
\mathrm{Z}=\mathrm{F}+\mathrm{M} \\
\text { Pendugaan laju eksploitasi }
\end{array}
$$

Pendugaan laju Mortalitas (Z) dengan menggunakan rumus yang dikemukakan oleh Beverton dan Holt (1956 dalam Sparre, 1992).

$$
\mathrm{Z}=\frac{\mathrm{K}(\mathrm{L} \infty-\mathrm{L})}{\mathrm{L}-\mathrm{LC}}
$$

\section{HASIL DAN PEMBAHASAN}

Laju mortalitas alami dihitung dengan menggunakan rumus empiris Pauly

$\log M=-0.0066-0.279 \log L \infty+$ $0.6543 \log K+0.4634 \log T$

$\mathrm{L}_{\infty}$ adalah panjang asimptotik, $\mathrm{K}$ adalah koefisien pertumbuhan instrinstik dan $\mathrm{T}=$ adalah suhu rata-rata tahunan $\left({ }^{\circ} \mathrm{C}\right)$. Pauly (1980) menyatakan bahwa laju mortalitas total merupakan hasil penambahan dari mortalitas

\section{Hubungan Panjang Bobot}

Hasil analisis panjang bobot Cumi Cumi ( $S$. Lessoniana diperoleh koefisien a sebesar 0,304, koefisien b sebesar 2,3995 dan nilai koefisien korelasi (R) dari hubungan panjang berat adalah 0,9799 menunjukkan keeratan hubungan panjang dan berat sebesar 97 $\%$ (Gambar 3)

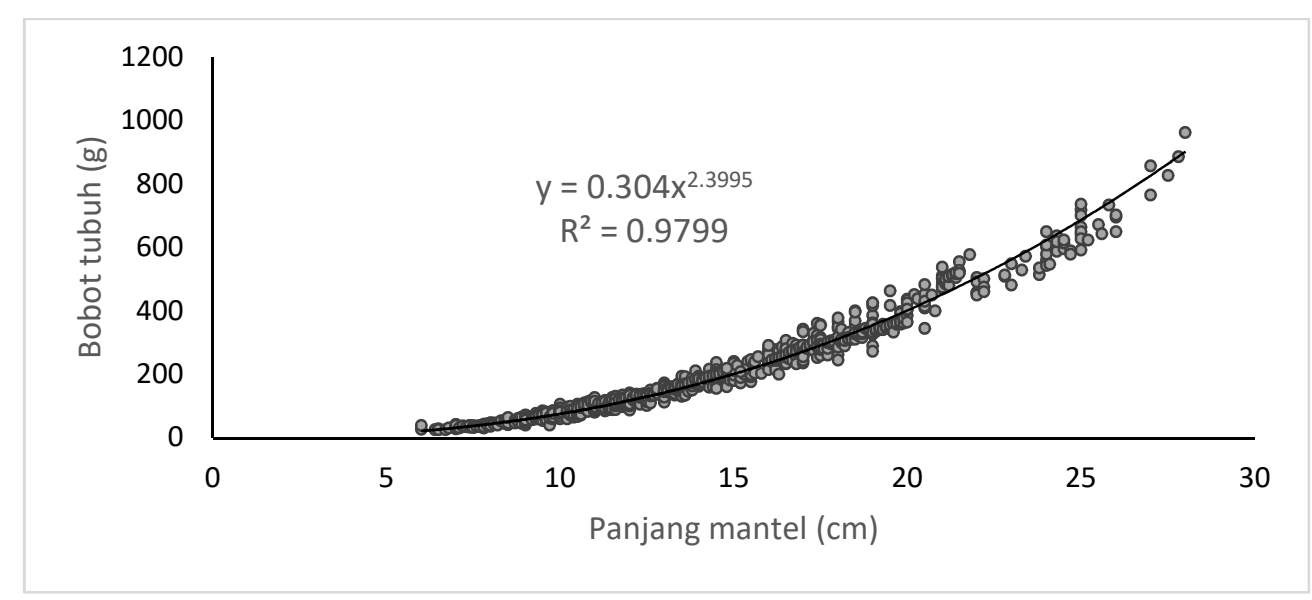

Gambar 2. Hubungan panjang bobot cumi cumi (S. Lessoniana) yang tertangkap selama penelitian 
Hasil analisis menunjukkan nilai $\mathrm{b}<3$, menunjukkan pola pertumbuhan allometrik negatif artinya pertambahan panjang lebih cepat dari pertambahan bobot. Hasil penelitian hubungan panjang bobot Cumi Cumi (Loligo chinensis) di Perairan Teluk Tomini oleh Nursinar et al, (2015), menunjukkan nilai $b>3$ menunjukkan pola pertumbuhan allometrik positif artinya pertambahan panjang lebih lambat dari pertambahan bobot.

\section{Sebaran Ukuran}

Sebaran ukuran Cumi Cumi ( $S$. Lessoniana) yang tertangkap seperti Gambar 4. menunjukkan sebaran nilai tengah kelas panjang Cumi Cumi $(S$. Lessoniana) berkisar antara $6,9 \mathrm{~cm} \mathrm{-}$ $27,0 \mathrm{~cm}$. Ukuran panjang dengan proporsi terbesar didapatkan pada nilai tengah kelas 10,9 cm sebesar 221 ekor dan ukuran panjang dengan proporsi terkecil didapatkan pada nilai tengah kelas $27,0 \mathrm{~cm}$ sebesar 8 ekor. Hasil penelitian di perairan Polewali Mandar oleh Sriwana (2007) mendapat kisaran panjang $8,0 \mathrm{~cm}$ sampai $27,2 \mathrm{~cm}$ dengan jumlah sampel 1099.

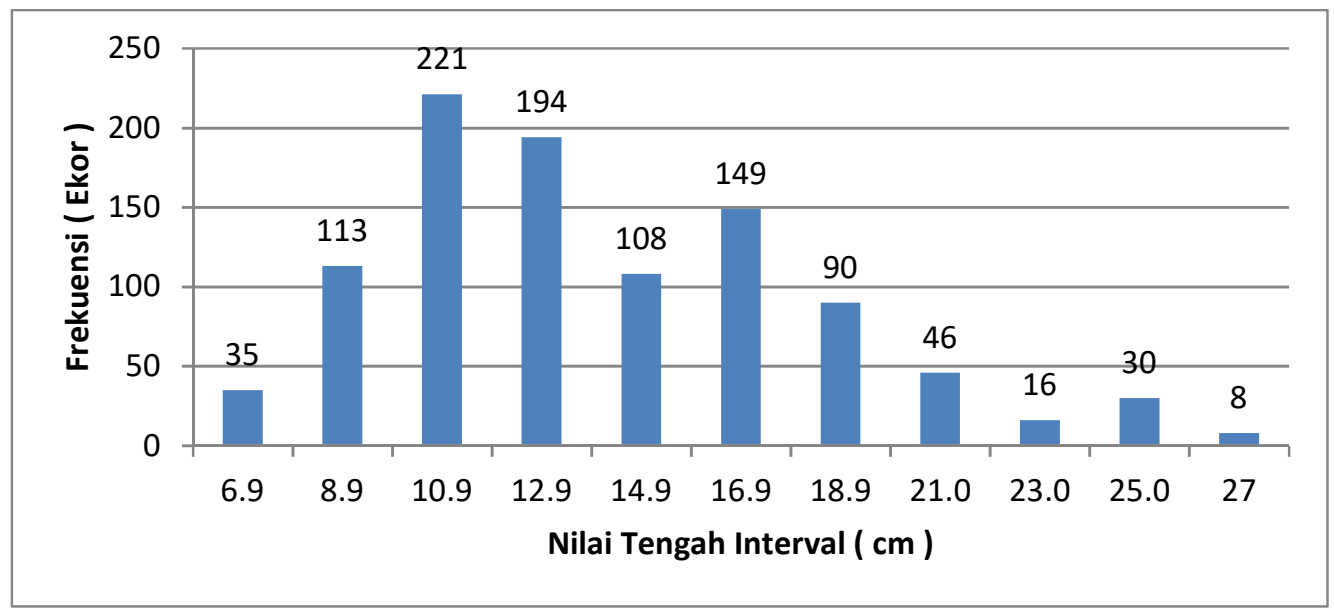

Gambar 3. Sebaran Ukuran Cumi Cumi (S. Lessoniana) yang tertangkap Di Kepulauan Spermonde selama penelitian

Hasil penelitian Muzakkir faktor lingkungan dan musim (2011), menunjukkan bahwa populasi penangkapan.

Cumi-Cumi (Loligo chinensis) di

Perairan Kabupaten Barru memiliki kisaran panjang $3,0 \mathrm{~cm}-16 \mathrm{~cm}$.. Adanya perbedaan ukuran Cumi Cumi yang tertangkap di duga di pengaruhi oleh

\section{Kelompok Umur}

Hasil analisis kelompok umur Cumi Cumi (S. Lessoniana) yang tertangkap di Kepulauan Spermonde seperti Gambar di bawah ini 


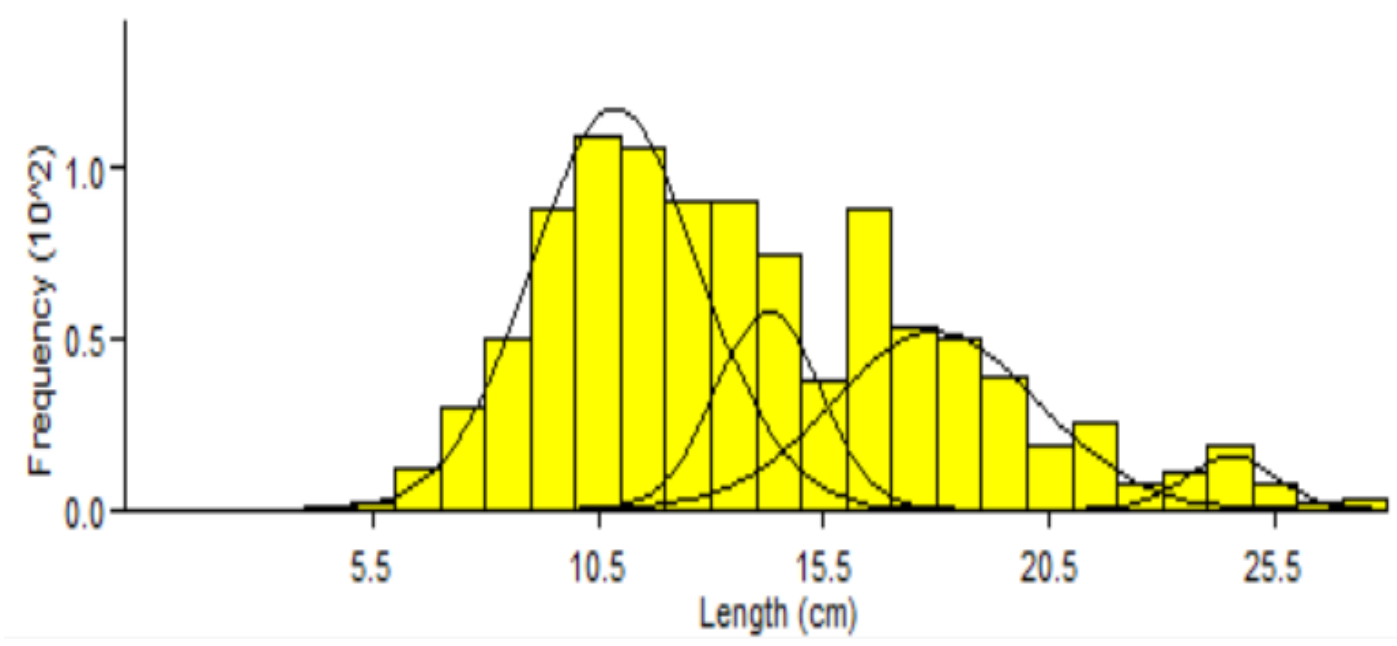

Gambar 4. Kelompok umur Cumi Cumi (S. Lessoniana) di Kepulauan Spermonde selama penelitian

Hasil analisis kelompok umur dimana masing masing kelompok umur menunjukkan bahwa Cumi Cumi $(S$. dengan rata rata kisaran panjang yang Lessoniana) di Kepulauan Spermonde berbeda (Tabel 2)

terdiri atas empat kelompok umur,

Tabel 2. Hubungan antara umur relatif dengan modus panjang rata rata dan populasi Cumi Cumi ( $S$. Lessoniana) yang tertangkap di Kepulauan Spermonde selama penelitian

\begin{tabular}{lcrr}
\cline { 2 - 4 } \multicolumn{1}{c}{ Lokasi } & Kelompok Umur & $\begin{array}{c}\text { Panjang rata rata } \\
(\mathrm{cm})\end{array}$ & Populasi (ekor) \\
\hline Kepulauan & I & 10,89 & 548,00 \\
Spermonde & II & 14,26 & 165,24 \\
$(2019)$ & III & 17,97 & 293,27 \\
& IV & 24,62 & 38,25 \\
\hline
\end{tabular}

Tabel diatas menunjukkan III dengan panjang rata masing masing kelompok umur I, II, III dan IV dengan $10,6973 \mathrm{~cm}, 18,1903 \mathrm{~cm}$ dan 20,5174 panjang rata rata masing masing $10,89 \mathrm{~cm}$ $\mathrm{cm}, 14,26 \mathrm{~cm}, 17,97 \mathrm{~cm}$ dan 24,52 cm. Hasil penelitian Nursinar et al. (2015), didapatkan Suntung (Loligo $s p$ ) yang tertangkap di Perairan Teluk Tomini Desa Olimoo'o terdiri atas 3 kelompok umur dimana kelompok umur I, II dan

4. Laju pertumbuhan (K) dan panjang maksimum yang bisa dicapai $(\mathrm{L}$ maks)

Hasil analisis laju pertumbuhan (K) dan panjang maksimum yg bisa 
dicapai (L maks) dari fungsi pertumbuhan Von Bertalanffy diduga dengan menggunakan Metode Gulland.

Dengan program Pizat II di peroleh

Tabel 3. Koefisien Laju pertumbuhan $(\mathrm{K})$, panjang maksimum (L maks) dan umur pada saat panjang $=0$ (to) Cumi Cumi (S. Lessoniana) di Kepulauan Spermonde selama penelitian

\begin{tabular}{cc}
\hline Parameter & Nilai \\
Populasi & 0,37 \\
\hline K $(/$ tahun $)$ & 31,50 \\
L maks $(\mathrm{cm})$ & $-0,4402$ \\
to & \\
\hline
\end{tabular}

Tabel 1 menunjukkan koef. laju pertumbuhan (K) cumi-cumi $(S$. lessoniana) di Kepulauan Spermonde 0,37 pertahun dan panjang maksimum $(\mathrm{L} \infty)$ yang dapat dicapai sebesar 31,50. Nilai $\mathrm{K}$ menunjukkan kecepatan pertumbuhan ikan, dimana semakin rendah nilai $\mathrm{K}$ semakin lama waktu yang dibutuhkan oleh ikan masing nilai laju pertumbuhan dan laju kematian seperti pada tabel di bawah ini:

untuk mencapai panjang maksimumnya. Hasil penelitian yang dilakukan diperairan Kabupaten Polewali Mandar diperoleh nilai parameter pertumbuhan $\mathrm{K}=0,0241$ per tahun, Lo sebesar $43,30 \mathrm{~cm}$ dan to sebesar -0.61 per tahun (Sriwana, 2007). Cumi-cumi yang tertangkap di Perairan Kab Barru memiliki Kecepatan laju pertumbuhan (K) sebesar 0,21 pertahun, panjang maksimum $(\mathrm{L} \sim) 26,7 \mathrm{~cm}$ dan to sebesar 0,82 pertahun (Muzakkir, 2011). Adanya perbedaan nilai yang didapatkan diduga dipengaruhi oleh perbedaan faktor lingkungan diantaranya ketersediaan makanan, habitat dll.

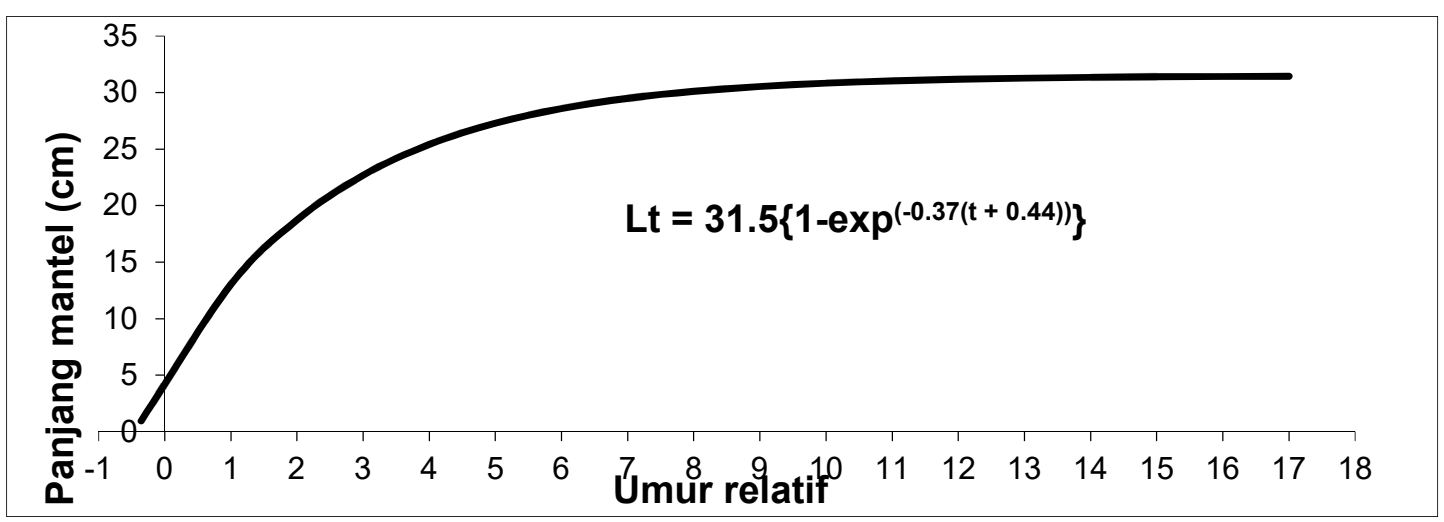

Gambar 5. Kurva pertumbuhan Von Bertalanffy Cumi Cumi ( $S$. lessoniana) yang tertangkap di Kep. Spermonde selama penelitian 
5. Mortalitas total (Z), mortalitas alami mortalitas alami sebesar (M) 0,19 per (M) dan mortalitas penangkapan (F). tahun,dan mortalitas

Hasil Analisis laju mortalitas penagkapan(F)sebesar 0,47 per tahun. (Pauly, 1980), Cumi Cumi (S. Hasil tersebut menunjukkan bahwa laju lessoniana) di Kepulauan Spermonde di mortalitas penangkapan lebih tinggi dari peroleh mortalitas total (Z) sebesar 2,85, pada laju mortalitas alami. mortalitas alami $(M)=0,69$, mortalitas penangkapan $(F)=2,31($ Tabel 2$)$

\section{Laju Eksploitasi}

Hasil analisis laju eksploitasi

Tabel 2.Laju kematian total (Z), laju kematian alami (M) dan laju kematian penangkapan (F), Cumi Cumi (S. lessoniana) di Kepulauan Spermonde

\begin{tabular}{ccc}
\hline $\begin{array}{c}\text { Parameter } \\
\text { Populasi }\end{array}$ & $\begin{array}{c}\text { Ernaningsih } \\
(2019)\end{array}$ & $\begin{array}{c}\text { Sriwana } \\
(2007)\end{array}$ \\
\hline $\mathbf{Z}$ & 2,85 & 0,66 \\
$\mathbf{M}$ & 0,95 & 0,19 \\
$\mathbf{F}$ & 1,90 & 0,47 \\
\hline
\end{tabular}

Nilai mortalitas alami (M), dapat dihubungkan dengan nilai koef pertumbuhannya $(\mathrm{K})$ di mana ikan yang tumbuh secara cepat mungkin memiliki nilai mortalitas alami yang tinggi dan sebaliknya ikan yang tumbuh secara lambat memiliki mortalitas alami yang rendah (Sparre and Venema, 1992). Hasil penelitian Cumi Cumi $(S$. lessoniana) di Kepulauan Spermonde menunjukkan mortalitas penangkapan lebih besar dari mortalitas alami. Hasil penelitian di perairan Kabupaten Polewali Mandar diperoleh nilai laju mortalitas total (Z) 0,66 pertahun, Cumi Cumi (S. lessoniana), di peroleh nilai E sebesar 0,67. Nilai laju eksploitasi sebesar 0,67 menunjukkan bahwa pemanfaatan sumberdaya Cumi Cumi di Kepulauan Spermonde menunjukkan telah terjadi kelebihan tangkap (Over eksploitasi). Nuraeni et al, (2013), menemukan laju eksploitasi Cumi Cumi (Loligo chinensis) di Perairan Kab Barru jenis jantan sebesar 0,87 per tahun dan betina 0.65 per tahun.

\section{Yield Per Rekruitmen}

Rekruitmen adalah penambahan anggota baru ke dalam suatu populasi. Sebagai penambahan tahunan ke suatu stok, rekruitmen merupakan dasar untuk kesinambungan suatu populasi (Nikolsky, 1963). Dengan memasukkan nilai $L \infty, K$, dan Lc, yield per rekruitmen relatif $(\mathrm{Y} / \mathrm{R})$ dari Beverton dan Holt (1957). 


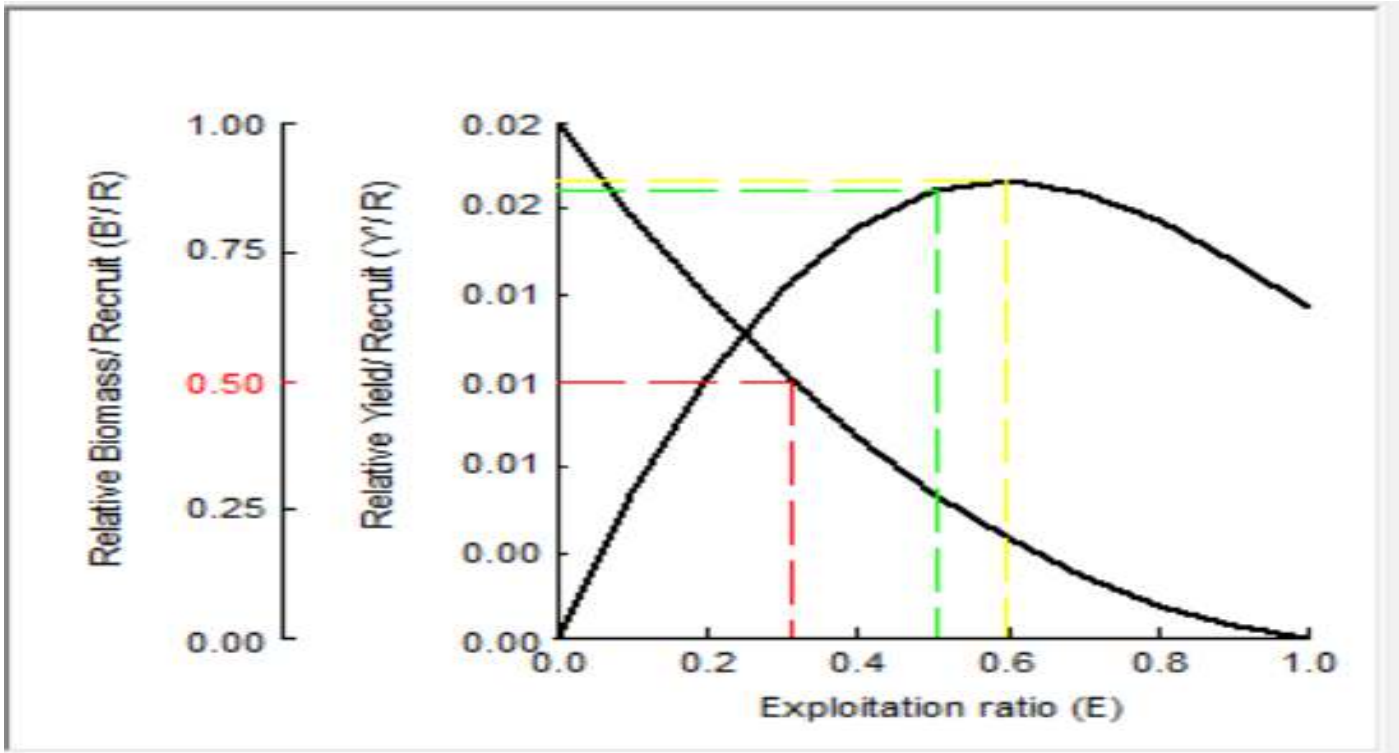

Gambar 6. Y/R relatife Cumi Cumi (S. lessoniana) pada berbagai laju eksploitasi di Kepulauan Spermonde

Berdasarkan Gambar diatas, terlihat bahwa $\mathrm{Y} / \mathrm{R}$ relatife dicapai pada laju eksploitasi berkisar 0,3. Peningkatan laju eksploitasi menyebabkan penurunan $\mathrm{Y} / \mathrm{R}$, jika laju eksploitasi dipertahankan seperti kondisi saat ini maka harus dilakukan upaya upaya pengelolaan seperti pengurangan jumlah alat tangkap, pengaturan ukuran mata jaring dan upaya restocking.

\section{KESIMPULAN}

Dari hasil penelitian parameter populasi dan tingkat eksploitasi Cumi Cumi (S. lessoniana) di kepulauan Spermonde selama penelitian disimpulkan sebagai berikut

1. Hubungan panjang bobot, allometrik minor. Sebaran ukuran panjang mantel yaitu $6,9 \mathrm{~cm}-27,0 \mathrm{~cm}$ dengan kelompok umur terdiri 4 kelas

2. Koefisien laju pertumbuhan (K), 0,37/thn menunjukkan bahwa Cumi Cumi (S. lessoniana) memerlukan waktu yang lama untuk mencapai panjang maksimumnya. Laju mortalitas penangkapan (F) lebih tinggi dari mortalitas alami $(\mathrm{M})$ dan laju eksploitasi 0,67 menunjukan pemanfaatan berlebih (over eksploitasi).

\section{SARAN}

Melihat besarnya laju eksploitasi yang melebihi batas potensi lestari (MSY) sehingga perlu dilakukan upaya pengelolaan misalnya dengan melakukan 
pengaturan ukuran mata pancing dan restocking dan perlu dilakukan rehabilitasi habitat serta pelarangan penangkapan yang bersifat merusak

\section{UCAPAN TERIMA KASIH}

Tulisan ini merupakan bagian dari penelitian Unggulan Internal yang dibiayai Universitas Muslim Indonesia melalui Lembaga Penelitian dan Pengembangan Sumberdaya Manusia (LP2S), terkait hal tersebut maka penulis mengucapkan terima kasih kepada Yayasan wakaf UMI Makassar yang telah membiayai penelitian ini pada tahun anggaran 2019.

\section{DAFTAR PUSTAKA}

Beverton RJH dan Holt SJ. 1957. On the dynamics of exploited fish population. Her Majesty's Statinery Office. London, USA. $533 \mathrm{p}$.

Ernaningsih, 2015. Bioekologi dan Eksploitasi Ikan Kerapu (grouper) di

Kepulauan Spermonde Sulawesi Selatan. Disertasi. Program Pascasarajana Universitas Hasanuddin.

Gayanilo, F.C. Jr., P. Sparre. And D. Pauly. 2005. FAO-ICLARM Stock Assessment Tools II (Fisat II), Revised version, User's guide. FAO Computerized Information Series (Fisheries). No. 8, Revised version, Rome, FAO. 168p.
Kurniawan, 2014. Pendugaan Beberapa Parameter Dinamika Populasi Cumi (Sephioteuthis lessoniana lesson,1830) Yang Tertangkap di Perairan Kota Makassar Sulawesi Selatan. Skripsi. Program Studi Pemanfaatan Sumberdaya Perikanan Jurusan Perikanan Fakultas Ilmu Kelautan dan Perikanan universitas Hasanuddin Makassar.

Muzakkir, 2011. Pendugaan Beberapa Parameter Dinamika Populasi CumiCumiLoligo chinensis Pada Perairan Barru Sulawesi Selatan. Makassar: Universitas Hasanuddin.

Nikolsky GV. 1963. The ecology of fishes. Academic Press. London \& New York. $203 p$.

Nuraeni L, Rapi dan Achmar Mallawa, 2013. Mortalitas dan Rasio Eksploitasi Cumi cumi (Loligo chinensis) di Perairan Kabupaten Barru. Jurnal Balik Diwa, Volume 4 No.1 JanuariJuni

Nursinar, Femy M, Sri Nuryatin , 2015, Analisis Dinamika Populasi Suntung (Loligo sp) di Perairan Teluk Tomini Desa Olimoo'o Kecamatan Batudaa Pantai. Laporan Hasil Penelitian.

Pauly, D. $1980 . \quad$ On The Interrelationships Between Natural Mortality, Growth Parameter and Mean Environmental Temperature in 175 Fish Stack. J.Cons CIEM (30: 175-192).

Pauly D. 1980. A Selection of Simple Methods for The Assessment of Tropical Fish Stocks. FAO 
Fisheries Circular. No. 729. 54 Wilson, S.K, M.S. Pratchett, N.A.J. p.

Graham, N.V.C. Polunin. 2010.

Habitat Degradation and Fishing

Sparre, P., and S.C. Venema, 1992. Introduction to Tropical Fish Stock Assesment Part 1. Manual FAO Fisheries Effect on The Size Structure of Coral Reef Fish Communities. Technical Paper No. 306. Rev1. Ecological Aplication, 20 (2). Pp. 442-451.

Rome. 376 p.

Sriwana, 2007. Pendugaan Parameter Dinamika populasi Cumi-cumi Sepioteuthis lessoniana Lesson,1830, Skripsi Program Studi Pemanfaatan Sumberdaya Perikanan, Jurusan Perikanan, Fakultas Ilmu Kelautan dan Perikanan, Universitas Hasanuddin. Makassar 